\title{
Environmental assessment and reclamation of abandoned marl mining dumps in the Northwest Caucasus
}

\author{
AV Alekseenko Saint Petersburg Mining University, Russia
}

\begin{abstract}
This paper discusses the assessment of the environmental impact of marl mining dumps within the industrial agglomeration of Novorossiysk city (Northwest Caucasus, Russia). It presents methods for the ecological and geochemical assessment of terrestrial and aquatic landscapes of the urban landscape and briefly describes field investigations, laboratory tests and statistical data processing used in the assessment. A technique for improving the ecological hazard estimation reliability for mine dumps was developed. It includes identification of poly-element geochemical anomalies and calculation of integral indicators for soil pollution and legacy contamination in the city, as well as the eco-risk of the probability of debris-flow occurrence at the dumps. The paper proposes a method for reducing the ecological hazard of the dumps in the agglomeration. The method is based on the analysis of modern approaches to landscape revitalisation and compares possible ways to stabilise the soil cover of the dumps. The proposed technical reclamation uses a geosynthetic cover and biological reclamation through hydro-seeding of a mixture containing soil amendments, understory and grass and selected woody plant species to reduce erosion. The results were accepted for implementation by the research-production and supervisory organisations of the city of Novorossiysk, and confirmed by three certificates. The technical proposals for abatement of the technogenic hazards and their impacts on the environment, developed in the course of research, can be used to improve the ecological situation within the urban areas of Novorossiysk. The proposed solutions for environmental protection may be used by mining enterprises that also generate waste dumps requiring reclamation to limit deflation and erosion and prevent pollution and debris flows.
\end{abstract}

Keywords: environmental geochemistry, soil pollution, trace metals, arid climate

\section{Introduction}

The cement factory in the Novorossiysk industrial agglomeration (NW Caucasus, Krasnodar Krai, Russia) was commissioned in 1882 and currently produces four million tonnes per year. Open pit mining of marl (carbonate-terrigenous upper cretaceous sedimentary rock with calcium carbonate $\left(\mathrm{CaCO}_{3}\right)$ content from 40 to $80 \%$ ) in the agglomeration is a source of raw material for Portland cement manufacturing. The abandoned marl mine dumps of the factory are hazardous because of fugitive dust emissions, erosion and the possible occurrence of a debris-flow disaster. To address this, an environmental geochemical study of the Novorossiysk industrial agglomeration was required to identify most hazardous sites and debris-flow-risk localities, as well as substantiate the need for reclamation to lower the technogenic burden of the mine dumps on the environment.

In the arid climatic conditions of the Black Sea coast (Figure 1), emissions from the cement plant and wind erosion of marl mining dumps have been major pollution sources in the Novorossiysk industrial agglomeration for over a century. Today the release of emissions from the Novoroscement plant has significantly reduced after new filtration systems were installed. However, as the mine wastes of the marl quarry have not been reclaimed, deflation of the topsoil horizon still persists. As Novorossiysk is a large recreation and tourism centre with more than 300 thousand residents which adjoins the mine site (Figure 2), it is necessary to assess the ecological safety of the local landscapes. 
The goal of this work was to reduce environmental geochemical and debris-flow-generation hazards caused by cement material production dumps. In order to achieve it, the following objectives were set:

1. Study pollutant migration and accumulation processes.

2. Analyse and assess of erosion-process hazards and debris-flow formation at the dumps.

3. Develop a mine dump reclamation program to reduce soil deflation and debris-flow threat.

\section{Precipitation, $\mathrm{mm} \quad$ Temperature, ${ }^{\circ} \mathrm{C}$}

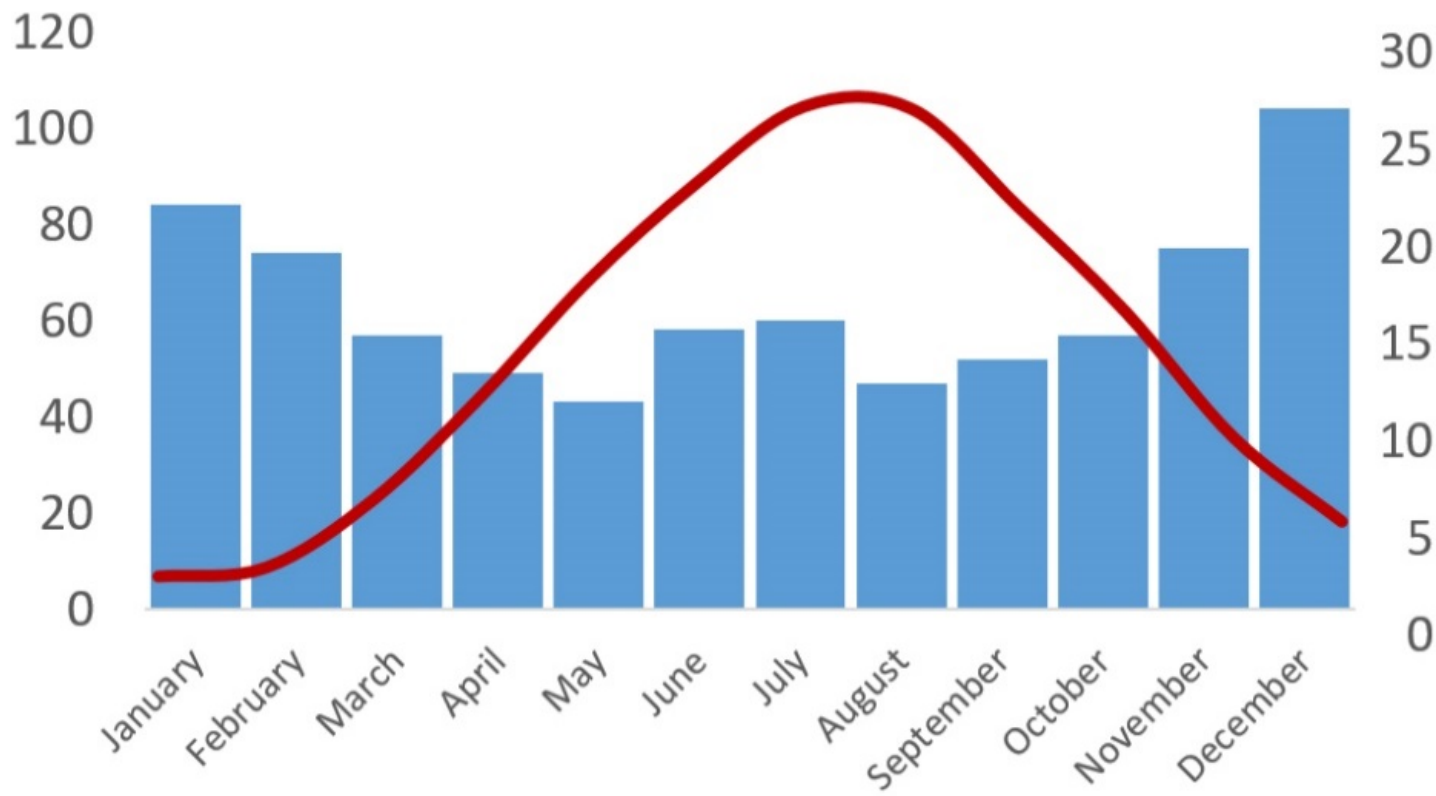

Figure 1 Climatic conditions of Novorossiysk city (after worldclimate.com)

\section{$2 \quad$ Materials and methods}

The research technique for the Novorossiysk industrial agglomeration included a number of steps.

1. Review and analysis of pollution processes in industrial agglomerations and the means used to reduce technogenic impact on the environment.

2. Environmental impact assessment.

a. Part a: field investigations with soil and plant sampling; threefold repeated field measurements of dust content (PM1-PM10) in the air.

b. Part b: chemical analysis of bulk chemical composition in specimens by spectral emission analysis (SEA) and inductively coupled plasma atomic emission spectroscopy (ICP); extraction and identification of mobile forms of heavy metals.

c. Part c: identification of geochemical associations of major pollutant elements in the soil and within plants found growing on the cover, and assessment of pollution eco-risk. Evaluation of accumulated environmental damage and technical risk of a debris flow.

3. Identification of the most efficient reclamation technique to ensure the environmental safety of the marl mining dumps. Planting of shrubs and trees for soil stabilisation on a sample plot. 


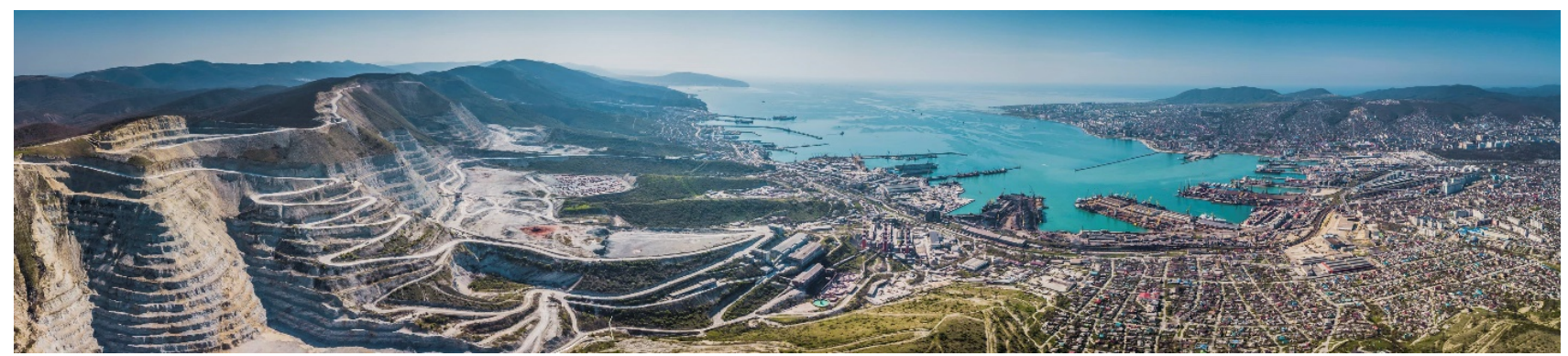

Figure 2 The Novorossiysk industrial agglomeration as viewed southwards from the Markoth Range (source: E Sorokin)

\section{Results and discussion}

\subsection{Geochemical impact assessment}

The data obtained formed the basis of a comprehensive characterisation of the ecological specifics of the landscapes (Figure 3), including assessment of the air, soil and water pollution features.

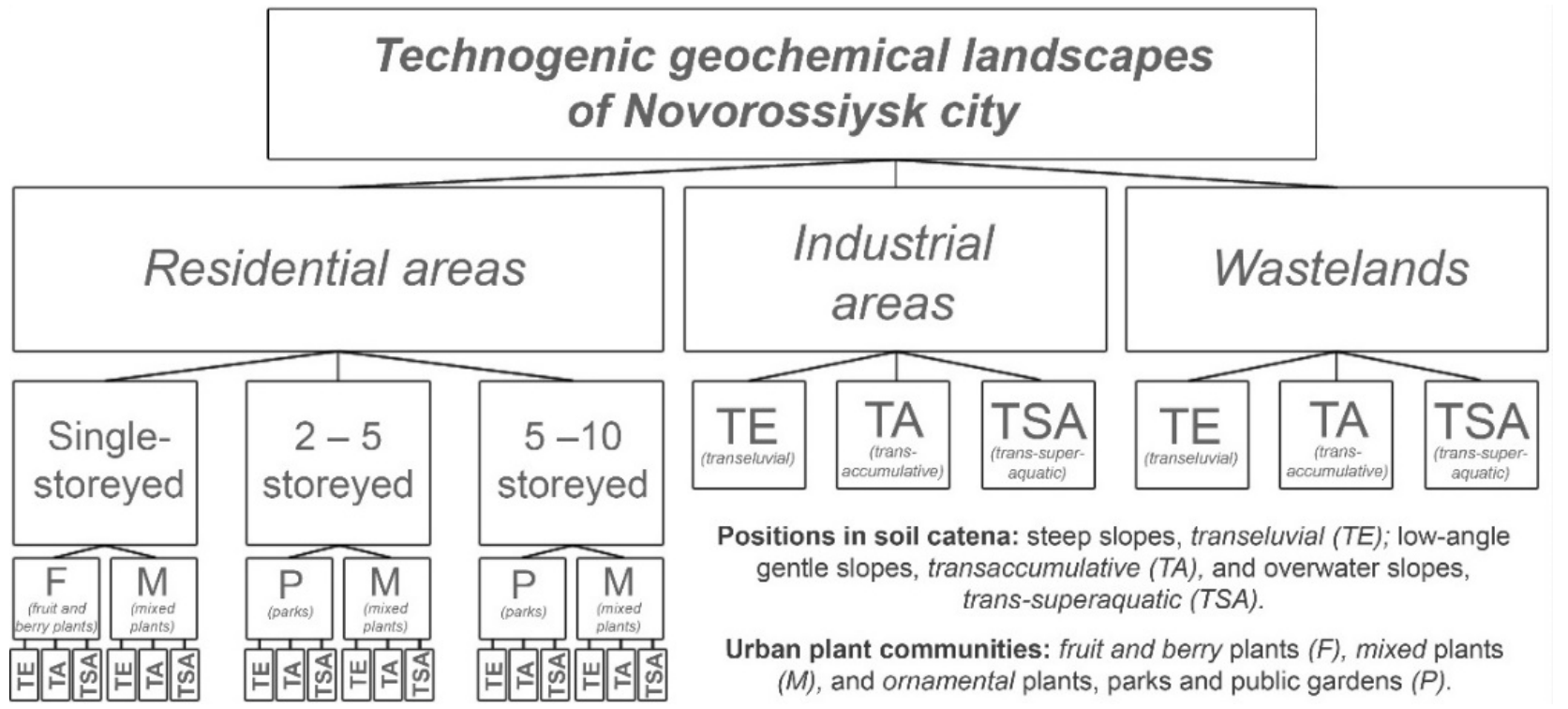

Figure 3 Zoning of the Novorossiysk industrial agglomeration based on changing land topography and vegetation types

The key pollutants were defined in the soil cover of Novorossiysk city by comparing local and regional background levels of metals, and calculating enrichment factors (EF). An accumulation of Sr-Zn-Pb-Cu-Ba (in geochemical association of elements), was revealed (Table 1). The identified geochemical association of basic polluting elements was revealed as their EFs were $>1.5$ in more than $50 \%$ of the samples. These metals demonstrate similar migration properties; their Cartledge ionic potential is below three, indicating weak ability to form complex ions, active dissolution of cations in aqueous media and accessibility for organisms. Similar values of the prevailing valences of these metal ions and their radii indicate the possibility of their joint migration in supergenic environments, as evidenced by the high percentage of mobile forms of metals extracted with the acetate-ammonium buffer.

The element concentrations were lower in the ash of Cystoseira (brown algae) growing in the zones under the influence of biogenic (natural) terrestrial landscapes than in those landscapes influenced by human activity. The highest average contents were noted at the observation points in the areas of urban waste water treatment plant discharge (Aleksino settlement) and breakwater area, facing the greatest impact of precipitating cement plant emissions. The lowest contents of all the elements considered, except for Mo, are 
generally characteristic for Cystoseira of the western biogenic coast (Drebenstedt \& Alekseenko 2019). The eastern biogenic coast is characterised by a slightly higher content of elements in comparison with the western one. The concentrations of five elements - $\mathrm{Cu}(41.7 \mathrm{ppm}$ ), $\mathrm{Zn}$ (48.3), $\mathrm{Pb}$ (10.3), $\mathrm{Co}$ (6.5) and $\mathrm{Cr}$ (1.0) are lower than those of Cystoseira sampled in the technogenic landscape influence zone. In this case, the concentrations of $\mathrm{Ni}, \mathrm{V}, \mathrm{Sn}, \mathrm{Mo}, \mathrm{Mn}$ and $\mathrm{Ti}$ are close to the values typical for the coastal strip of Novorossiysk.

Table 1 Element contents $(\mathrm{mg} / \mathrm{kg})$ in the soils of undisturbed areas and the soils of the agglomeration

\begin{tabular}{|c|c|c|c|c|c|c|c|c|c|c|c|c|}
\hline $\begin{array}{l}\text { Chemical } \\
\text { element }\end{array}$ & $\mathrm{Ba}$ & Co & $\mathrm{Cr}$ & $\mathrm{Cu}$ & Li & Mo & $\mathrm{Ni}$ & $\mathrm{Pb}$ & Sn & Sr & v & $\mathrm{Zn}$ \\
\hline $\begin{array}{l}\text { Background } \\
\text { concentration }\end{array}$ & 800.0 & 21.0 & 137.0 & 58.0 & 52.0 & 2.6 & 48.0 & 42.0 & 5.1 & 340.0 & 143.0 & 123.0 \\
\hline $\begin{array}{l}\text { Average } \\
\text { concentration } \\
\text { in urban soils }\end{array}$ & 940.0 & 20.5 & 77.4 & 75.5 & 50.0 & 2.1 & 46.0 & 69.2 & 5.2 & 875.4 & 69.2 & 214.0 \\
\hline
\end{tabular}

In the absence of direct technogenic impact, the effect of pollutants precipitating from the air remains, even on the coast with forest landscapes. It should be noted that the mine is located on the eastern shore of the bay, and the increased metal content in algae may be related to the influence of atmospheric emissions (Heras 2009).

\subsection{Risk levels}

The current state of the environment of the industrial agglomeration was assessed using chemical analysis, field descriptions of the key sites and sampling points, geological maps, Global Mapper digital elevation models with remote sensing data, Birds Eye space images of the Russian SAS-Planet database, as well as findings from literature. Disturbed lands were ranked by degree of eco-risk by calculating the percentage of the territory where the pollutant element contents exceed the Maximum Permissible Concentrations in soils coast (Drebenstedt \& Alekseenko 2019); the proportion makes up less than $30 \%(\mathrm{Cu}, \mathrm{Zn})$ to $62 \%(\mathrm{~Pb})$ and $100 \%(\mathrm{Sr})$. The maximum exceedance of the state-established reference standards (analogously to EF) is $\mathrm{As}_{50} \mathrm{~Pb}_{19} \mathrm{Zn}_{9} \mathrm{Cu}_{2}$.

Calculation of the Cumulative Pollution Index showed that over $50 \%$ of the entire study area (about $30 \mathrm{~km}^{2}$ ) can be characterised as moderate-eco-risk or high-eco-risk in terms of pollutant element accumulation in its topsoil horizon. The calculated environmental damage to the soil cover after its pollution and overlap by mining wastes accounts for RUR 176.8 million (ca. USD 2.3 million).

Dumps pose an environmental threat being a source of dust and unstable mine-waste, vulnerable to debris-flows. The key risk factors are the bare surface of the dumps and the difficulty of establishing vegetation without special land-improvement measures, leading to rain and wind erosion. In the vicinity of Novorossiysk, potential debris flows can consist of soil and loose sediments overlapping (flowing over) parent rock. Up to $65 \%$ of the loose rock mass in a debris flow can consist of 1-10 cm-sized fragments of marl stored in the dumps. A debris flow on the Black Sea coast of the Caucasus can be caused by:

1. Waterspouts: i.e. vertical water funnels. About 10 occur each summer season in this region (as in the catastrophic flood of 2002); and

2. Annual precipitation and extreme storms. On average, 15 debris flows occur in this region annually.

The calculated cost of this geotechnical risk takes into account estimates of debris flow probability, and damage inflicted by these rare events. Losses can amount to RUR 17.85 million (ca. USD 240 thousand) average annual damage in the Novorossiysk industrial agglomeration. The proposed approaches to the ranking of technogenic areas and assessment of eco-risks provide the basis for the development of actions aiming at reducing ecological hazards due to the presence of the mine dumps. 


\subsection{Reclamation technique}

The threat of dust spread and debris-flow can be reduced by reclamation, ensuring the stability of the dumps. Two types of dump surfaces are described:

1. Sub-horizontal levelled surfaces that measure $45,000 \mathrm{~m}^{2}$ with the grade not exceeding $15^{\circ}$; and

2. Slopes with grades of $15-45^{\circ}$ over the area of $105,000 \mathrm{~m}^{2}$.

Type (1) areas do not require any special engineering preparation of the surface before the application of soil-stabilising plants. In type (2) areas, the biological stage of slope reclamation is only possible after stabilisation of the soil surface prior to commencing reclamation work (Cooke \& Johnson 2002).

A number of comparative studies were conducted into ways to use the land after its reclamation (Bangian et al. 2012; Doley et al. 2012; Maczkowiack et al. 2012; Mborah et al. 2016; Narrei \& Osanloo 2011). These studies showed that the optimal treatment within the Novorossiysk industrial agglomeration is achieved by covering a slope surface with erosion-control geosynthetics. This is a fibre-structured rolled material consisting of several layers of extruded polypropylene mesh, superimposed on each other and mechanically or thermally bound by a polypropylene yarn. A large number of voids is needed to create the best conditions for grass establishment when hydro-seeding with a mixture of soil amendments and seeds of herbaceous plants. In addition, the mesh provides protection against erosion and acts as a filter, preventing the washout of fine soil particles (Figure 4).

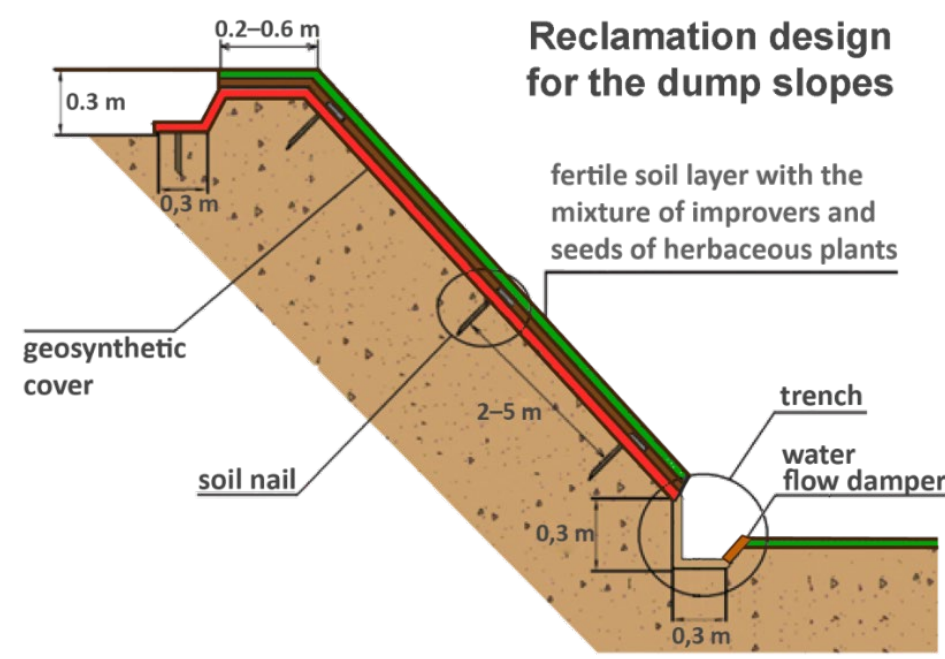

Figure 4 Slope stabilisation measures at the dumps

Plantation of a biocenosis, including cade and smoke trees on sub-horizontal surfaces was carried out on an experimental plot and showed the suitability of these trees and shrubs adapted to the dry climatic conditions of the Northwest Caucasus (Figure 5). The optimal time for tree planting is the late summer, prior to the heavy rainfall autumn-winter period when the soil is sufficiently wet, and the formation of a stable phytocenosis will begin in the second year. Rehabilitation with the seed of herbaceous plants - legume (Fabaceae) and grasses (Poaceae) - will provide undergrowth and the necessary environment for proper maintenance of geochemical cycles of plant nutrients within the landscape (Caravaca et al. 2003; Coates 2005).

Expenditure of RUR 16.06 million (ca. USD 230 thousand) for reclamation is justified as it may prevent further environmental damage and subsequent destruction caused by storms and catastrophic events. Assuming that all proposed reclamation solutions are implemented, the formed vegetation cover will support the natural processes of soil formation at the dumps (Jordán et al. 2016; Sourkova et al. 2005). The ultimate result of designated steep slope stabilisation and tree plantation at sub-horizontal sites is the transformation of the technogenic dumps into a biogenic system, characterised by high resistance to erosion and debris flows (Zhao et al. 2013), as well as the ability to autonomously function without further human intervention. 


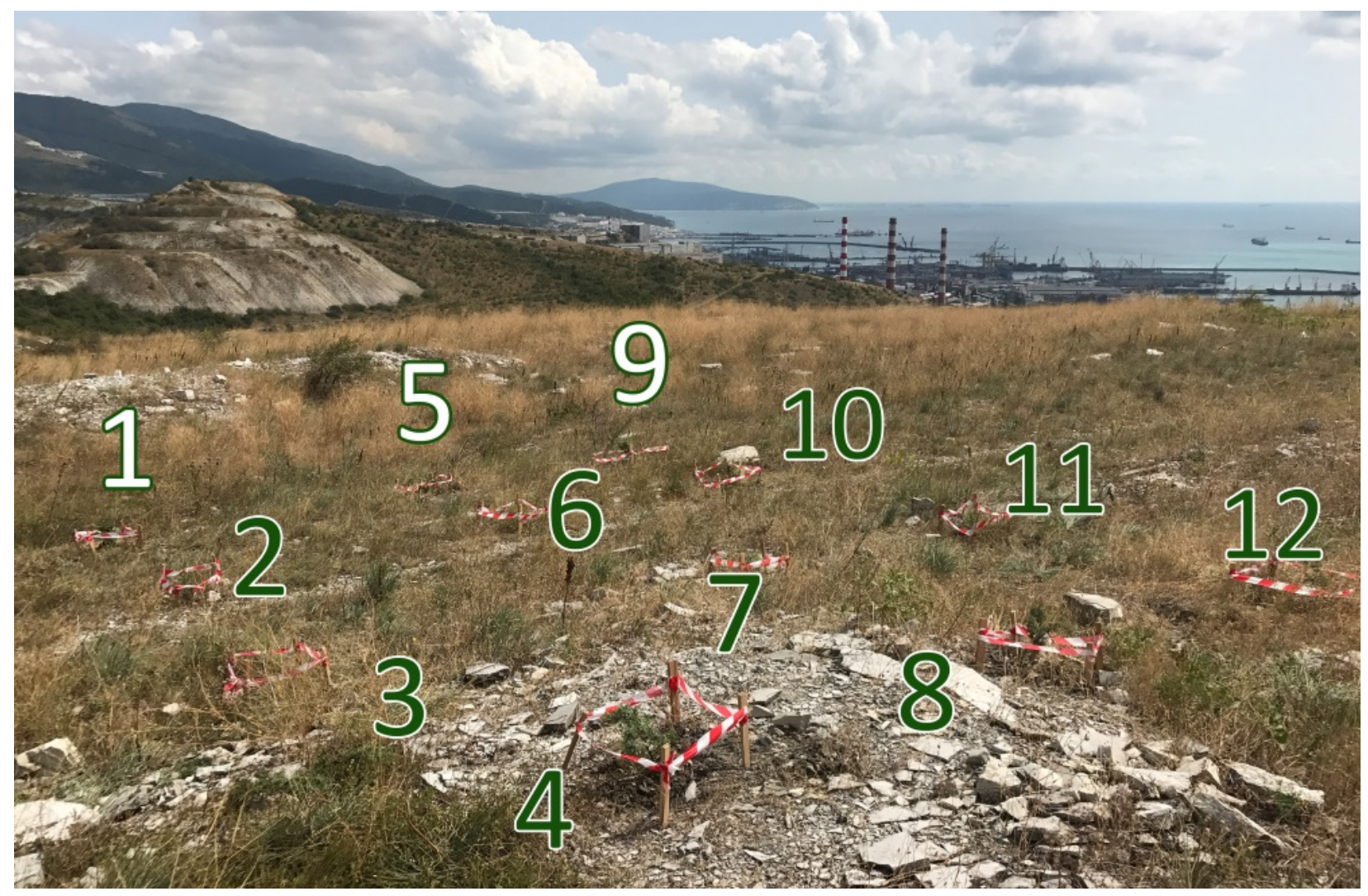

Figure 5 Experimental plantation plot of Juniperus oxycedrus L. cades (Nos. 2, 3, 4, 6, 7, 8, 10, 11 and 12) and Cotinus coggygria Scop. smoke trees at the dump benches (Nos. 1, 5 and 9)

\section{Conclusion}

The field and laboratory research studies identified the migration and accumulation of pollutant elements from industrial activities into the urban terrestrial, and aquatic landscapes; fugitive dust transport from the dumps to central and residential areas of the city was described and concentration of the association of $\mathrm{Pb}$, $\mathrm{Zn}, \mathrm{Cu}, \mathrm{Ba}$ and $\mathrm{Sr}$ in the urban environment was established.

Environment monitoring of the landscape-geochemical effects of the Novorossiysk industrial agglomeration was performed, areas of high environmental risk caused by soil pollution were identified and the Cumulative Pollution Indexes and economic losses caused by accumulated environmental damage were calculated. The threat of erosion and debris flows were analysed and assessed in the areas of overburden and substandard marl dumps, the technical risk was calculated taking into account a number of harmful impact types and the frequency of each emergency scenario was calculated.

A system of environmental protection actions, building a case for dump reclamation has been developed, including a set of debris-flow and erosion-control measures which, if implemented, would reduce the environmental hazards of the dumps by:

1. Hydro-seeding with soil amendments (improvers) and grasses.

2. Planting trees and shrubs that grow well in the arid subtropical climate of the Black Sea coast of the Northwest Caucasus.

3. Covering the slopes with geosynthetics; 


\section{Acknowledgement}

I am grateful to my Research Advisor, Professor Mariya Pashkevich, whose insight and expertise greatly assisted the research. I acknowledge Professor Carsten Drebenstedt for academic advice during my semi-annual internship in Technische Universität Bergakademie Freiberg. I am thankful to Associate Professor Dmitriy Nagornov for giving pointed remarks. The studies were performed using the equipment of the Common Use Centre of the Saint Petersburg Mining University.

\section{References}

Bangian, AH, Ataei, M, Sayadi, A \& Gholinejad, A 2012, 'Optimizing post-mining land-use for pit area in open-pit mining using fuzzy decision making method', International Journal of Environmental Science and Technology, vol. 9., pp. 613-628.

Caravaca, F, Alguacil, MM, Figueroa, D, Barea, JM \& Roldan, A 2003, 'Re-establishment of Retama Sphaerocarpa as a target species of reclamation of soil physical and biological properties in a semi-arid Mediterranean land', Forest Ecology and Management, vol. 182 , no. 1 , pp. 49-58.

Coates, W 2005, 'Tree species selection for a mine tailings bioremediation project in Peru', Biomass Bioenergy, vol. 28, no. 4, pp. 418-423.

Cooke, JA \& Johnson, MS 2002, 'Ecological restoration of land with particular reference to the mining of metals and industrial minerals: a review of theory and practice', Environmental Reviews, vol. 10, pp. 41-71.

Doley, D, Audet, PP \& Mulligan, DR 2012, 'Examining the Australian context for post-mined land rehabilitation: reconciling a paradigm for the development of natural and novel ecosystems among post-disturbance landscape', Agriculture, Ecosystems and Environment, vol. 163, pp. 85-93.

Drebenstedt, C \& Alekseenko AV 2019, 'Environmental impact of abandoned mine wastes on an urban area in NW Caucasus', Proceedings of the 11th Russian-German Raw Materials Conference, CRC Press, Leiden, pp. 223-229.

Heras, MML 2009, 'Development of soil physical structure and biological functionality in mining spoils affected by soil erosion in a Mediterranean-Continental environment', Geoderma, vol. 149, pp. 249-256.

Jordán, MM, Bech, J, García-Sánchez, E \& García-Orenes, F 2016, 'Bulk density and aggregate stability assays in percolation columns', Journal of Mining Institute, vol. 222, pp. 877-881.

Maczkowiack, RI, Smith, CS, Slaughter, GJ, Mulligan, DR \& Cameron, DC 2012, 'Grazing as a postmining land-use: a conceptual model of the risk factors', Agricultural Systems, vol. 109, pp. 76-89.

Mborah, C, Bansah, KJ \& Boateng, MK 2016, 'Evaluating alternate post-mining land-uses: a review', Environment and Pollution, vol. 5, no. 1 , pp. $14-22$.

Narrei, S \& Osanloo, M 2011, 'Post-mining land-use methods optimum ranking, using multi attribute decision techniques with regard to sustainable resources management', OIDA International Journal of Sustainable Development, vol. 2, no. 11, pp. 66-76.

Sourkova, M, Frouz, J, Fettweis, U, Bens, O, Hutl, RF \& Santruckova, H 2005, 'Soil development and properties of microbial biomass succession in reclaimed post mining sites near Sokolov (Czech Republic) and near Cottbus (Germany)', Geoderma, vol. 129, pp. 73-80.

Zhao, Z, Shahrour, I, Bai, Z, Fan, W, Feng, L \& Li, H 2013, 'Soils development in opencast coal mine spoils reclaimed for 1-13 years in the West-Northern Loess Plateau of China', European Journal of Soil Biology, vol. 55, pp. 40-46. 
